\title{
Influence of Third Opinion Leaders on Decision Making Quality: A Case on Financial Decision Making
}

\author{
Nik Maheran Nik Muhammad, DBA
}

Universiti Malaysia Kelantan nikmaheran@umk.edu.my

Rikinorhakis Ridwan

Universiti Malaysia Kelantan rikiuitm08@gmail.com

Doi:10.5901/mjss.2015.v6n2s5p292

\begin{abstract}
Many top leaders nowadays are relying on external parties to get ideas and information for more effective and quality decisionmaking. For certain leaders, the power of thinking partners is the factor of success in their decision making process. This study therefore aimed to identify the influence of third opinion leaders in enhancing the relationship between leadership styles and financial decision-making quality. Based on the initial work of Joni (2004) and Path-Goal theory, with 211 usable respondents using hierarchical regression analysis, shows that the quality of financial decision is significant and positively related to leadership behavior. Third opinion's mind and third opinion's relationship act as pure moderator, while third opinion's focus was found to be a quasi-moderator. For theoretical implication, the findings suggest that the inclusion of the moderating variable will further enhance the understanding of the differential impact of leadership style under various contexts of decision-making situation, in this case, the third opinion. For future research, it is recommended that differences relation to leadership behavior should be studied more extensively to reach various kinds of comparative conclusions.
\end{abstract}

Keywords: leadership styles, Third opinion, Path-Goal theory

\section{Introduction}

Today's work environment is becoming increasingly turbulent and therefore leaders must take the responsibility to make good or quality decisions in order to ensure the survival of the organization (Moss and Kinnear, 2007). Managers often have incomplete information and insufficient time to make decisions, and by delaying decisions they can negatively affect the organization. When making decisions, some researchers suggest that managers should try to gather information from many levels of the organization or outside of the organization from various sources or parties. They must remember that the source of information that they get may not be reliable or accurate and they have to keep in mind that an incorrect decision could have an impact on the organization and understand that changes in the work environment can affect their decisions. These researchers also believe that the most important thing for managers is to take responsibility for the results and not blame others when things go wrong because by pointing fingers at others will only erode the trust and respect for them (Kaval, and Voyten, 2006).

According to Flynn, Goldsmith, and Eastman (1996), there are two types of related parties in the process of opinion leaders which are "information seekers" (i.e. a person or a leader looking for advice or suggestions from others), and the second is "the informant" (i.e. a person or leader who provides advice or opinions). Thus, previous studies have explored the factors that affect the ability of a person to influence others was conducted in the work environment such as the advice network (Gibbons, 2004) and also in non-work environment (Oygard, 2003).

Findings from other research on opinion leaders were used by Chaney (2001) in marketing decision making and have been used to test the customer decision-making style where it focused on the quality of a decision made by an individual (Scheufele, 1999) and also study the effectiveness of an organization (Emden, Calantone and droge, 2006). At the same time, (Roger and Kincaid, 1981) have argued that opinion leaders have been assessed as "an individual who often influences the attitude and behavior of others". This individual has been identified as a "provider of information and advises other members". Therefore, Weimann et al. (2007) explain that opinion leaders are more preferable to influence the quality of the decision using mouth-to-mouth communication. 
Decisions and leadership are compatible pairs. Great leaders seem to make more than their share of good results. Drucker (2001) said, "The decision is of specific tasks for an executive, how to make a decision is regarded as the biggest single contributor to successful leadership". Great leaders and great results essentially are interrelated. One solution is to share and delegate decision-making throughout the organization (Confida, 2004) through opinion and third opinion leadership.

Third opinion is a leadership style adopted from the idea of Joni (2004) which relies on outsider's opinion in influencing the decision-making process. Joni (2004) has proposed three characteristics of third opinion which is being used in this study. There are third opinion's mind: people with knowledge and high thinking level; third opinion's relationship: people with personal trust and networking; and third opinion's focus: people who have idea, creativity and innovativeness. This research advocates that third opinion is contingent upon the relationship between leader's behavior initiated from Path-goal theory by House and Mitchell (1974) and Situational theory by Hersey and Blanchard (1977). Leaders' behavior therefore is conceptualized based on four dimensions namely directive behavior, supportive behavior, participative behavior and achievement-oriented behavior.

The quality of financial decisions is important for the leaders and also for their organizations. Effective decision leaders are committed to the ultimate goal of achieving high quality decision (Kouzes and Posner, 2007). According to Carr and Brower (2000), making decisions in good order is the result of quality decision-making processes. He also argued that one who successfully sets up strategy decisions arising from decision processes is one in which individuals and organizations find and process information efficiently in varying situations. There are various types of financial decisions which are related to financial investment decisions, in connection with the acquisition of assets related to business expansions and the management of loans and credit in connection with mergers and acquisitions and others.

\section{Background of the Study}

Initial studies on opinion leadership begins from the work of Lazarsfeld, Berelson, and Gaudet, in which the first was founded by Katz and Lazarsfeld (1955), and then was reviewed by Rogers (2003), Cross, Laseter, Parker and Velasquez (2006) and Weimann, Tustin, Vuuren and Joubert (2007). The majority of work on opinion leadership focuses on motivating opinion leaders (Chan and Mirsa, 1990), measurement of current issues (Childers, 1986; Flynn, Goldsmith and Eastman 1994), and the results of opinion leadership (Bloch, 1986). However, this concept requires a consensus definition if one wants to use it effectively.

Rogers (2003) stated that an opinion leader is "an individual who gives the number of unequal influence on the decisions made by other people". Understanding leadership as an influence of personal opinion is clear, concise and compact, and if one looks at the work done since that time, one can see that it is all based on a preliminary study before (Kyun, 2007). Joni (2004) then introduced the term "third opinion leadership" that indicates many top leaders nowadays are relying on external parties to get ideas in a more effective and quality decision-making.

Economic growth and strong financial condition is an important part of the corporate world. With technological advancements, market integration and competitive markets have increased the demand to produce good and correct decisions. Consequently, Malaysia, like the rest of the world has doubled its efforts to transform the economy to achieve higher value and added growth. Therefore, more efficient mechanisms are required to ensure successful transformations. However, something happened in the corporate sector in Malaysia in 2001 where due to the resignation of Tun Daim Zainuddin (a very influential financial adviser to Malaysia's prime minister in 2001, Tun Dr Mahathir) from the political world has caused organizations of Renong-UEM and Malaysian Airlines System (MAS) to experience a severe fall (Asia Times, 2001). In this regard, the government had to take over Renong-UEM, Malaysia Airlines System (MAS), Malaysia Resource Corp Bhd (MRCB) and Kuala Lumpur light rail operators PUTRA and STAR, in an effort to reduce the growing debt levels and normalize the situation which had weakened due to the fall in stocks. This shows that the importance role of external consultants or better known as "third opinion" that is experienced in the business world, particularly in the areas of finance, in influencing the decision to strengthen organizational performance is very important. In addition, a similar problem affected to Bank Islam Malaysia Berhad (BIMB) which suffered significant losses and many small shipping companies listed on Bursa Malaysia (The Star, 2005) as well as many small and medium sized firms that could not endure stability in the market.

Following these incidents, many researchers have agreed that "the performance of each company depends entirely on the management of organizational leadership. In short, it is associated with a person's ability to manage an organization and how they get ideas and information from outside parties to make wise decisions" (The Star, 2005). Therefore, the right decision together with external information obtained from experts allows the company to take advantage of the decision-making errors that could lead to a decline and whose continued weakness would affect the 
income of the organization in the future. A good decision can lead to success which helps strengthen organizational performance. On the other hand, a bad decision can lead to bankruptcy. Goleman (2001) also believes that outside intervention in making quality financial decisions can help a person deal with and improve critical situations that are sensitive in nature.

There are various types of third opinion such as thinking partners, public opinion and others. For presidents or higher ranking leaders, they will use the power of public opinion to support their decision making. Kernell (2007) argued that the president who appeals to the public would be effective if the president "communicates on a regular basis as his top priority to citizens" and citizens respond by making good changes in public opinion. For certain financial leaders, the power of thinking partners will also be the factor of success in making decisions (Hoffberg and Korver, 2006). They have to make wise choices of their third opinion to help them determine certain decisions. Best "thinking partners" must have a high potential and be able to think beyond boundaries (Joni, 2004).

Rogers and Agarwala-Rogers (1976) have classified that opinion leaders can be regarded as informal leaders. Besides having a high technical ability, others are attracted to these opinion leaders because they "can be trusted and will lead the norms of a group" (Leonard-Barton and Kraus, 1985). Joni (2004) who pioneered the concept of a third opinion recognized that the external environment is important in creating better outcomes for decision making. Her case studies conducted in the United States prove that the hierarchy of leaders in the organizations (from the lower leaders to senior leaders) needs information from outside the organization in making the best decisions.

\section{Motivation of the Study}

According to Rost (1993), leadership is not only the work of a single person; rather it is a "collaborative endeavor", which is a relationship between leaders, followers or expert opinion that contributes to the decision making process. Tuckman and Jensen (1977) discovered a progression of development in external people's interaction that when completed adequately, led to higher quality decisions (Kerr and Tindale, 2004). Hinsz and Nickell (2004) stated that "group decisionmaking is always advisable" or "group decision making is always bad" than making decisions alone. But, when it comes to financial decisions, Sutter (2005) claimed that the decision in a group or the involvement of other parties namely third opinion is better than individual decisions. .

However, studies on third opinion are still in its infancy stage since the introduction of the term by Joni (2004). Earlier studies on opinion leadership are only related to consumer (Weimann, et al., 2007) and marketing decisions (Yuen, 2007). To the knowledge of the researcher, none has been found to relate opinion leadership to financial decision making such as assets acquisitions or investment decisions. This gap has motivated the researcher to investigate the contribution of third opinion leadership to financial decision quality in relation to leadership style possessed by decision makers. Hence, the purpose of the study is to determine whether or not third opinion leaders influence the quality of financial decisions and the characteristics of third opinion chosen by the decision makers.

\section{Literature Review}

Decision-making is a key aspect of leadership in any organization, whether public or private. Leadership plays a tremendous role in the processes and applications of decision-making. Quality of decision is important for the leaders and also for the organization. Effective decision leaders are committed to ultimate goal of achieving high quality decisions (Kouzes and Posner, 2007). According to Carr and Brower (2000), make a decision in good order are the result of a quality decision-making process. He also argued that one who successfully set up strategy decision arising from decision process is one in which individuals and organizations find and process information efficiently in varying situations.

In making a good financial decisions, as well as quality, Simon (1987) pointed out that, decision makers must know more about the industry, social and business environment in which they work. Quality of financial decision is a decision that has to meet organizational objectives and create a positive impact on decision-makers. A decision quality depends on the decision making process in which a decision maker organized, prioritized, aims and filled with a variety of information (Simon 1987). The way successful leaders approach the decision-making process changes as he or she moves up in the organization (Brousseau, Driver, Hourihan and Larsson, 2006). Thus, some leaders make decision based on their own judgment and some will refer to other people's opinion before further judgment is made. Leadership style that seeks and gives opinion from and to others is called opinion leadership style. 


\section{Leader's Behavioral Style}

There are four common leadership behaviors which have been introduced by House and Mitchell (1974) and House (1977) from Path-Goal Theory: directive, supportive, participative, and achievement-oriented styles. It is assumed that leaders are flexible, and that the same leader can display any or all of these behaviours depending on the situation. (1) Directive Behavior Style is behavior of a direct order to subordinates where the leader or manager lets subordinates know what they should be doing, making the schedule work, coordinating the work, providing specific mentoring, and provide an explanation of policies, laws, regulations and work procedures. (2) Supportive Behavior Style is the behavior that is directly related to the satisfaction of needs and interests of subordinates as displaying concern for the welfare of subordinates, creating friendship and support in a good working environment (House and Mitchell, 1974) (3) Participative Behavior Style is the behavior directly influencing the direction of encouraging subordinates to make decisions about the operations of the work unit, negotiating with subordinates and taking their opinions and suggestions when making decisions. It has also been referred to as collective decision-making or at least shared influence in decision making by the superiors and their employees (Koopman and Wierdsma, 1998; Yukl, 2002). (4) Achievement-oriented Behavior Style is the behavior directly related to encouraging excellence in performance by setting challenging goals, seeking improvement, showing excellence in performance and portraying confidence that subordinates will achieve quality performance. All the type of Leader's behavior

\section{Third Opinion}

The discipline of opinion leadership study has its roots in the work of Lazarsfeld, who investigated the 1940 presidential election (Goldsmith and De Witt, 2003). Following this, Katz and Lazarsfeld (1955) dedicated an entire volume to personal influence in the consumption process, concluding that communication flows from the source to the opinion leaders, who pass it on to the others in the social system. In the corporate context, opinion leaders play an important role in advice networks and communities of practice (Cross et al. 2006). In e-commerce settings, opinion leaders are crucial in determining trends (Herring et al. 2005) and in influencing shopping behavior (Chan and Mirsa 1990). Joni (2004) then introduced the term third opinion leadership and indicates that many top leaders nowadays relying on external parties to get ideas for more effective and quality financial decision-making. For certain leaders, the power of thinking partners will also be the factor of success in making the decision (Hoffberg and Korver, 2006). Thus, third opinion is a thinking partner, a partner with whom someone can think more profoundly with (Business Network, 2010). Third opinion leaders can be classified as anyone who is a consultant or a family member to the decision maker. They act as an advisor or supporter to the decision maker (Business Network, 2010). In certain countries, external people or "third opinion leaders" influence the actions of legislators, get laws passed or change the rules for government agencies (Kahai and Sosik, 1997). Third opinion leaders on the other hand are also the filters of ideas and information. Joni (2004) believes that the third opinion leader will help the decision maker in making quality decision.

According to Joni (2004), there are three characteristics of third opinion leaders: (1) Third Opinion's Mind which is defined as people with knowledge and high thinking level (Ennis, 2001). Third opinion mind were described based upon three levels of thinking skills namely, (i) skills to identify the characteristics of a problem and know how to find solution, (ii) deep understanding and (iii) expertise in specific fields of knowledge such as finance, economics, technology or science, and expertise in one or more fields of knowledge; (2) Third Opinion's Relationship which refers to the networking or with whom leader have contact. Leaders developed relationship based on personal trust such as through family member, friends or consultant; and (3) Third Opinion's Focus refers to someone with ideas, creativity and innovativeness. According to Canfield, Hansen, and Hewitt (2000), focus can be a powerful tool for helping an individual to achieve goals and decision quality but can also interfere with a person's efforts at goal attainment (Locke and Latham, 1990).

Many researcher has found that, third opinion intervention plays an important role between leaders behavior and decision making quality. According to Krantz and Kunreuther (2007), if someone seeks more information from other people or sources, they can make effective decision. It is supported by Joni (2004) that leaders today need someone who can support them to give good suggestion and opinion in making good decision. Katz and Lazarsfeld (1955) and Weimann, Tustin, Vuuren and Joubert (2007) argued that third opinion will give new idea and innovation to the leaders to make great decisions. Thus, it is proposed that third opinion is a contingent factor upon leaders behavior and decision making quality. 


\section{Research Findings}

\subsection{Leader's and Company's profile}

Unit of analysis for this study is decision and purposive sampling was used to distribute the questionnaires to 500 respondents but only 225 questionnaires were returned. However, a total of 14 questionnaires which contained incomplete answers were not used. Thus, a total of 211 questionnaires were used and analyzed. The total response rate for this survey was $42.2 \%$.

According to the sample, 57.8 percent of the respondents were males and the remaining 4.42 percent were females. 34.6 percent of the respondents were less than 30 years of age, 39.8 percent were between 30 to 39 years of age, 20.9 percent were between 40 to 49 years old, and 4.7 percent of the respondents were aged between 50 to 58 . According to the sample of 211 respondents, 86.3 percent of the respondents were Malays, 9.5 percent were Chinese, and 4.3 percent represented the Indian race. With regards to education, the highest number (46.4 percent) of the respondents completed the first degree at bachelors level. 21.8 percent of the respondents completed their study at diploma level and 21.3 percent of the respondents hold Masters degree.

The job profile of decision makers showed that the majority of the respondents in this study (24.6 percent) worked in the banking sector. 19.4 percent is a business owners. The other respondents worked in the manufacturing sector (16.1 percent), service sector (14.7 percent) and the rest of the respondents worked in other sectors such as tourism and hospitality. In terms of who made the decisions, the majority of the Idecision-makers in this sample were the middle manager (40.3\%) designated as heads of department or heads of programs followed by managers (38.9\%) who were branch managers, team leaders and project leaders. 20.9 percent comprised upper manager level that is Chief Executive Officers (CEO), Chief Financial Officers (CFO), Directors and Business Owners.

It is argued that different decisions need different types of external references of individuals (third opinion). Therefore, it is crucial to scrutinize the decision profile as it might point towards different leaders behavior. The data shows that most of the decisions in the sample are related to asset acquisitions such as computers, land, etc. (34.29\%), and $26.98 \%$ are related to financial investments (shares, bonds, etc). Another $22.86 \%$ are decisions related to loan and credit management, $8.89 \%$ are related to business expansion and the final $6.98 \%$ are the decisions related to mergers and acquisitions. Refer to Table 1

\subsection{Third Opinion's Profile}

To measure the level of third opinion being used in making financial decision, Table 2 indicates that the majority of the respondents state that third opinions were moderately used in their financial decision making (37.9\%); 31.8 percent frequently used third opinions in their making of financial decisions; and only 15.2 percent state that they were high frequent users in referring to third opinions for their financial decision making process. The rest of the respondents rate that they rarely rely on third opinions in making financial decisions (14.7\%) and 0.5 percent never rely on third opinions in their decision making.

In terms of types of third opinions sought by the leaders/decision makers, 22.76 percent of the decision makers stated that they relied on media for third opinion information, 18.85 percent sought opinions from consultants, 18.16 percent from friends, 16.09 percent from associations/clients, 14.48 percent from families and 9.66 percent from their business colleagues.

\subsection{Descriptive Analysis}

Descriptive analysis in general indicate that the most opinion sought by the decision maker were those from individuals with knowledge and high thinking level. Thus, 'Third Opinion Mind' were among the highest influence to the decision maker with mean of 5.75 followed by 'Relationship' (mean=5.37) and 'Focus" (mean=5.16). Refer to table 3.

Test of Differences

In general, there are no significant differences between the 'third opinion' and the respondents' profiles. There are also no significant differences between third opinion needed and types of financial decisions made. However, for third opinion's mind and third opinion's focus, Post Hoc tests show differences only between organization and position of the decision makers. The significance different was also found between leadership behavior and third opinion.

Decisions made by managers who worked as Business Owners prefer to seek third opinion's mind (mean=5.9) and as compared to those who work in the government and banking sectors who seek more for third opinion focus. 
(mean=5.4). Upper and middle managers seem to have a similar degree of agreement based on referring to third opinion's mind (both have mean=5.8). Lower managers, however, have the lowest degree of referring to third opinion's mind but were found to have the highest degree of referring to third opinion's focus .

In general, it shows that directive leaders prefer to seek for people who have creative ideas and innovativeness (third opinion's focus). Supportive and participative leaders on the other hand prefer people whom they trust and have high networking and good relationships with them (third opinion's relationship). For achievement-oriented leaders, they prefer people with knowledge and high thinking level (third opinion's mind). Thus, results on test of differences can be summarized in Table 4.

\subsection{Test of Relationship}

Hierarchical regression shows that third opinion's focus is quasi-moderator for leaders behavior and decision making quality. This indicates that those leaders (third opinion) who are full with ideas, creativity and innovativeness has direct and contingent effect to financial decision quality. Third opinion's mind and third opinion's relationship on the other hand act as pure moderator as they have no direct effect and only enhancing the relationship between leader's behavior and financial decision making quality.

Decision makers that possess achievement-oriented behavioral style relying on third opinion mind (i.e. individual with skills and experience) and third opinion relationship (i.e network and trust) to achieve their financial quality decision. Those with directive behavioral style on the other hand relying on third opinion mind. Participative behavioral style and directive behavioral style relying on third opinion relationship and third opinion focus (i.e, creativity and innovative) respectively. However, leaders with supportive behavior styles need no influence from top opinion leader. Thus, the findings reveal that certain leadership behavioral styles need different type of third opinion leadership as moderator.

\section{Conclussion and Recommendation for Future Research}

The findings of the study indicates that third opinion was moderately sought by the decision maker in their decision making process. Most of the third opinion leaders sought by the decision makers are third opinion mind which are those with skills and knowledge. The present study found that decision makers who are a business owners, upper level manager and posess achievement-orented leadership style prefer to rely on third opinion mind, in their decision making process. Third opinion mind also enhance the relationship between the achievement oriented behavior with financial decision making quality.

However decision makers who work at the government and banking sectors; those from lowers level position and decision makers with directive behavioural style sought most from the third opinion focus as they prefer someone who prossess great ideas, creative and innovative. The results is consistence with Kerr and Tindale, (2004) and Weimann, Tustin, Vuuren and Joubert (2007) confer that third opinion may give new ideas and innovation to the leaders to make great decisions. Decision makers with suportive and participative syles would prefer to rely on those people who are close to them and people who they trust (third opinion relationship).

Waldman Ramfrez, House and Puranam (2001) studies have confirmed that leaders' style affects group-work process, social climate, organization performance, quality decision and results. Evkall and Ryhammar (1998) explained that the leadership style can influence the work environment in decision making, which eventually producing a product or service quality. This is because; leadership styles have a direct impact on productivity and performance of an organization. Different dimension of leadership style will impact a different result of decision making (Goleman, 2000).

For future research, it is suggested that the differences in relation to leadership styles should be studied more extensively to reach various conclusions of comparison. Moreover, it is important to recognize the nature and source of the effect of institutions on leadership style that would become the most important goals in research leadership in the era of globalization, which is full of business activities.

It is also suggested that research related to leadership styles in a different country can be used as a valuable channel for studying the influence of national culture or ethnicity in the manager's leadership style with different nations and peoples in terms of external people (third opinion). Future studies may want to consider, for example, the impact of management values and strategic orientation of the organization or firm's leadership style among managers. In addition, future research could also examine the relationship between leadership styles, third opinion and the firm's performance in Malaysia.

In addition, Miller (1994) also says that organizational culture encompasses the values and norms that support the extent to which managers can look for an outsider (third opinion) to help make effective decisions. In summary, to 
increase the internal validity of research results, a larger sample size and the use of random sampling should be used for future research. Cultural factors and intermediate effects of the leadership style are also items that need to be reviewed in the future.

\section{References}

Borgatti, S. P. (2006). Identifying Sets of Key Players in a Social Network.

Brousseau, K., Driver, M., Hourihan, G., and Larsson, R. (2006), "The Seasoned Executive's Decision-Making Style", Harvard Business Review, Vol. 84 No.2, pp.111-21.

Business Network, CBS News. Why Every Leaders Needs a Third Opinion. (June 1 2010). www.bnet.com

Canfield, J., Hansen, M. V. and Hewitt, L. (2000). The Power of Focus. Deerfield Beach, Fl: Health Communications.

Carr, J. B. and Brower, R. S. (2000) 'Principled Opportunism: Evidence from the Organizational Middle', Public Administrative Quarterly, 24(1): 109-138.

Chan, K. K., and Mirsa, S. (1990). Characteristics of the Opinion Leader: A New Dimension. Journal of Advertising, 19(3), 53-60.

Chaney, I. M. (2001). Opinion Leaders as a Segment for Marketing Communications. Marketing Intelligence and Planning, 19(5), 302308.

Clegg, S. R., Hardy, C., and Nord, W. (1996) (Eds.) Handbook of Organizational Studies. Thousand Oaks, CA: Sage Publications, Inc.

Cross, R.., Laseter, T., Parker, A., and Velasquez, G., "Using Social Network Analysis to Improve Communities of Practice," California Management Review, Vol. 49, No. 1:32-60, 2006.

Dubrin, A. J. (1995), Leadership: Research Findings, Practice, and Skills. Boston: Houghton Mifflin Company.

Dulewicz, V., and Higgs, M. J. (2000). Emotional Intelligence: A Review and Evaluation Study. Journal of Managerial Psychology, 15(4), 341-368.

Emden, Z., Calantone, R. J., and Droge, C. (2006). Collaborating for New Product Development: Selecting the Partner with Maximum Potential to Create Value. The Journal of Product Innovation Management, 23:330-341.

Ennis, R. (2001) An Outline of Goals for A Critical Thinking Curriculum and Its Assessment in Costa, A. (Ed.) Developing Minds: A Resource Book for Teaching Thinking. Alexandria, VA: Association for Supervision and Curriculum Development.

Evkall G, and Ryhammar L (1998) Leadership Style, Social Climate and Organizational Outcomes: A study of Swedish University College. Creativity Innovative Management 7: 126-182.

Flynn, L. R., Goldsmith, R. E., and Eastman, J. K. (1996). Opinion Leaders and Opinion Seekers: Two New Measurement Scales. Journal of the Academy of Marketing Science, 24(2), 137- 147.

Goldsmith, R. E., and De Witt, T. S. (2003). The Predictive Validity of an Opinion Leadership Scale. Journal of Marketing Theory and Practice, 11(1), 28-35.

Goleman, D. (2000) Leadership That Gets Results. Harvard Business Review 78: 78-90.

Handy, C. B. (1982). Understanding Organizations. London: Penguin.

Herring, S. C., Kouper, I., Paolillo, J. C., Scheidt, L. A., Tyworth, M., and Welsch, P. (2005). Conversations in the blogosphere: An analysis "from the bottom-up". In Proceedings of the 38th Hawaii International Conference on System Sciences (HICSS'05). Los Alamitos: IEEE Press.

Hoffberg, K., and Korver, C. (2006). Great Leadership, Great Decisions, Great Outcomes. Decision Quality Index , 1-16.

House, R. J. (1971). A Path-Goal Theory of Leader Effectiveness. Administrative Science Quarterly, September, 321-338.

House, R. J. (1977) A 1976 Theory of Charismatic Leadership. In J. G. Hunt and L. L. Larson (Eds.) Leadership: The cutting edge. Carbondale; Southern Illinois University Press.

House, R. J., and Mitchell, R. R. (1974). Path-goal theory of leadership. Journal of Contemporary Business, 3, 81-97.

Joni, S.-n. A. (2004). The Third Opinion: How Successful Leaders Use Outside Insight to Create Superior Results. New York: Penguin Group (USA) Inc.

Kahai S., and Sosik J. (1997) "Effects Of Leadership Style and Follower's Cultural Orientation on Performance in Group and Individual Task Conditions". Personnel Psychology. Vol. 50. № 1, pp. 121-147.

Katz, E., and Lazarsfeld, P. F. (1955). Personal Influence. New York: Free Press.

Kaval, V., and Voyten, L. J., (2006). Executive Decision-making: Effective Processes for Making and Implementing Decisions. Healthcare Executive, 21(6), 16-22.

Keren, G., and Bruin, W. B. (2003). On the Assessment of Decision Quality: Considerations Regarding Utility, Conflict and Accountability. In D. Hardman, and L. Macchi, Thinking: Psychological Perspectives on Reasoning, Judgment and Decision Making. (pp. 348-363). Pittsburgh: John Wiley and Sons, Ltd.

Koopman, P. L., and Wierdsma, A. F. M. (1998). Participative Management. In P. J. D. Doentu, H. Thierry, and C. J. de-Wolf (Eds.), Personnel psychology: Handbook of work and organizational psychology (Vol. 3, pp. 297-324). Hove, U.K.: Psychology Press/Erlbaum.

Kouzes, J., and Posner, B. (2007). The Leadership Challenge. New York, NY: Jossey Bass, a Division of John Wiley and Sons.

Krantz, D. H., and Kunreuther, H. C. (2007). Goals And Plans in Decision Making. Judgment and Decision Making, 2(3), 137-168 (June).

Locke, E. A., and Latham, G. P. (1990). A Theory of Goal Setting and Task Performance. Englewood Cliffs, NJ: Prentice Hall.

McCaffery, P. (2004), The Higher Education Manager's Handbook: Effective Leadership and Management in Universities and Colleges. 
London and New York: RoutledgeFalmer.

Moss, H.K., and Kinnear, T.L. (2007). Nothing Can Eliminate Responsibility. Supervision, 68(1), 3-4.

Northouse, P. G. (2001). Leadership: Theory and Practice (2nd Ed.). Thousand Oaks, CA: Sage.

Oygard, L. "Divorce Support Groups: What Factors are of Importance Regarding Friendship Development in the Groups?" Social Work with Groups, Vol. 26, No. 4, 2003.

Partington, D. A. (2003). Managing and Leading. In J. R. Turner (Ed.), People in project management. Aldershot, UK: Gower.

Podsakoff, P. M., MacKenzie, S. B., Paine, B., and Bacharach, D. (2000). 'Organizational Citizenship Behavior: A Critical Review of the Theoretical and Empirical Literature and Suggestions for Future Research'. Journal of Management, vol. 26, no. 3, pp. 513-563.

Rogers, E. M. and D. L. Kincaid (1981), Communication Networks: Toward a New Paradigm for Research, New York: The Free Press.

Scheufele, D. A. (1999). Participation as Individual Choice: Comparing Motivational and Informational Variables and Their Relevance for Participatory Behavior. Unpublished doctoral dissertation, University of Wisconsin, Madison.

Sharma, S., Durand, R.M., and Gur-Arie, O. (1981). Identification and Analysis of Moderator Variables. Journal of Marketing Research, 18, 291-300.

Sharma, V. K. (2003). Period Responses to Zeitgeber Signals Stabilize Circadian Clocks during Entrainment. Chronobiol. Int. 20:389404.

Simon, H. A. (1987). Making Management Decisions: The Role of Intuition and Emotion. Academy of Management Executive, 1, 57-64.

Waldman D, Ramfrez G, House R, and Puranam P. (2001) Does Leadership Matter, Ceo Leadership Attributes and Profitability Under Conditions of Perceived Environmental Uncertainty. Acad. Manag. J. 44: 134-143.

Weimann, G., Tustin, D. H., Vuuren, D. v., and Joubert, J. P. (2007). Looking for Opinion Leaders: Traditional vs. Modern Measures in Traditional Societies. openUP, 1-18.

Yukl, G. (2002). Leadership in Organizations. (5th ed.) Upper Saddle River, NJ: Prentice Hall.

\section{Tables and Figures}

Table 1: Financial Decision Profile

\begin{tabular}{l|c|c}
\hline & Frequency & Percentage (\%) \\
\hline Financial Investments (share, bond, etc) & 85 & 26.98 \\
Assets' Acquisition (computer, land, etc) & 108 & 34.29 \\
Business Expansion & 28 & 8.89 \\
Loan and Credit Management & 72 & 22.86 \\
Mergers and Acquisitions & 22 & 6.98 \\
\hline
\end{tabular}

Table 2: Third Opinion Profile

\begin{tabular}{|c|c|c|}
\hline \multicolumn{3}{|l|}{ Decisions (N=211) } \\
\hline & Frequency & Percentage (\%) \\
\hline $\begin{array}{c}\text { Reference to Third Opinions } \\
\text { Never } \\
\text { Rare } \\
\text { Moderate users } \\
\text { Frequent users } \\
\text { Highly frequent users }\end{array}$ & $\begin{array}{c}1 \\
31 \\
80 \\
67 \\
32\end{array}$ & $\begin{array}{c}0.5 \\
14.7 \\
37.9 \\
31.8 \\
15.2\end{array}$ \\
\hline $\begin{array}{c}\text { Type of third opinions that leaders/decision makers sought } \\
\text { Friends } \\
\text { Business colleagues } \\
\text { Association / Clients } \\
\text { Family } \\
\text { Consultant } \\
\text { Media (Newspaper, magazines, electronic, etc) }\end{array}$ & & $\begin{array}{l}.16 \%) \\
.66 \%) \\
.09 \%) \\
.48 \%) \\
.85 \%) \\
.76 \%)\end{array}$ \\
\hline
\end{tabular}

Table 3: Descriptive statistics of Variables

\begin{tabular}{ccccc}
\hline \multicolumn{5}{c}{ Decision N = 211 } \\
\hline Variables & Min. & Max. & Mean & Std. Dev \\
\hline Third Opinion & & & & \\
\cline { 2 - 2 } & 4.00 & 7.00 & 5.75 & .66743 \\
Relationship & 4.00 & 6.60 & 5.37 & .62129 \\
Focus & 3.25 & 6.50 & 5.16 & .61495 \\
\hline
\end{tabular}


Table 4: Test of Difference

\begin{tabular}{|c|c|c|c|c|c|c|}
\hline & \multicolumn{6}{|c|}{ Third Opinion } \\
\hline & \multicolumn{2}{|c|}{ Mind } & \multicolumn{2}{|c|}{ Relationship } & \multicolumn{2}{|c|}{ Focus } \\
\hline & F-value & P-value & F-value & P-value & F-value & P-value \\
\hline Respondents' Profiles: & & & & & & \\
\hline Age & 1.928 & 126 & .720 & .541 & 1.433 & .234 \\
\hline $\begin{array}{l}\text { Education } \\
\text { Job Profiles }\end{array}$ & 1.713 & 166 & .552 & .582 & 1.388 & .248 \\
\hline Organization & 2.428 & $.036^{*}$ & .822 & .535 & 2.990 & $.013^{\star}$ \\
\hline Position & 4.613 & $.011^{*}$ & 1.419 & .244 & 4.321 & $.014^{*}$ \\
\hline $\begin{array}{c}\text { Types of Financial Decisions } \\
\text { Leaders 'Behavior }\end{array}$ & 1.008 & .404 & 1.515 & 199 & .708 & .587 \\
\hline Directive & 2.936 & $.000^{\star \star \star}$ & 2.409 & $.003^{* \star}$ & 3.475 & $.000^{* \star *}$ \\
\hline Supportive & 1.374 & .153 & 2.528 & $.001^{\star \star}$ & 1.869 & $.023^{\star}$ \\
\hline Participative & 1.806 & $.030^{*}$ & 2.133 & $.007^{\star *}$ & 1.568 & .076 \\
\hline Achievement-oriented & 2.642 & $.001^{\star \star}$ & .853 & .617 & 2.553 & $.002^{\star \star}$ \\
\hline
\end{tabular}

Significant level: ${ }^{* \star *}<0.000,{ }^{* *}<0.01,{ }^{*}<0.05$

Table 5: Hierarchical Analysis Result

\begin{tabular}{|c|c|c|c|c|c|c|}
\hline \multirow{4}{*}{ Model Variables } & \multicolumn{6}{|c|}{ Dependent Variable } \\
\hline & \multicolumn{6}{|c|}{ Quality of Financial Decisions } \\
\hline & \multicolumn{2}{|c|}{ Model 1} & \multicolumn{2}{|c|}{ Model 2} & \multicolumn{2}{|c|}{ Model 3} \\
\hline & Std. beta & Sig. & Std. beta & Sig. & Std. beta & Sig. \\
\hline $\begin{array}{l}\text { 1. Independent variables: } \\
\text { Directive } \\
\text { Supportive } \\
\text { Participative } \\
\text { Achievement-oriented }\end{array}$ & $\begin{array}{l}.186 \\
.215 \\
.203 \\
.201\end{array}$ & $\begin{array}{l}.013^{\star} \\
.003^{\star \star} \\
.006^{\star *} \\
.008^{\star \star}\end{array}$ & $\begin{array}{l}.055 \\
.144 \\
.209 \\
.159\end{array}$ & $\begin{array}{l}.429 \\
.033^{\star} \\
.002^{\star \star} \\
.026^{\star}\end{array}$ & $\begin{array}{l}-1.738 \\
-.793 \\
1.307 \\
2.041\end{array}$ & $\begin{array}{l}.021^{\star} \\
.230 \\
.030^{\star} \\
.0 .28^{\star}\end{array}$ \\
\hline $\begin{array}{l}\text { 2. Moderating variables: } \\
\text { Mind } \\
\text { Relationship } \\
\text { Focus }\end{array}$ & \multicolumn{2}{|l|}{-} & $\begin{array}{l}.131 \\
.125 \\
.266 \\
\end{array}$ & $\begin{array}{l}.034^{\star} \\
.041^{\star} \\
.000^{\star \star \star}\end{array}$ & $\begin{array}{l}-.466 \\
-.096 \\
1.301\end{array}$ & $\begin{array}{l}.474 \\
.899 \\
.021^{\star}\end{array}$ \\
\hline $\begin{array}{l}\text { 3. Interaction variables: } \\
\text { 1. Mind x Leadership Style } \\
\text { Mind_Directive } \\
\text { Mind_Supportive } \\
\text { Mind_Participative } \\
\text { Mind_Achievement }\end{array}$ & & & & & $\begin{array}{l}2.232 \\
.845 \\
1.677 \\
-4.112 \\
\end{array}$ & $\begin{array}{l}.020^{\star} \\
.365 \\
.080 \\
.000^{\star \star \star}\end{array}$ \\
\hline $\begin{array}{l}\text { 2. Relationship x Leadership Style } \\
\text { Relationship_Directive } \\
\text { Relationship_Supportive } \\
\text { Relationship_Participative } \\
\text { Relationship_Achievement }\end{array}$ & & & & & $\begin{array}{l}-1.494 \\
1.040 \\
-2.015 \\
2.715\end{array}$ & $\begin{array}{l}.071 \\
.354 \\
.049^{\star} \\
.002^{\star \star}\end{array}$ \\
\hline $\begin{array}{l}\text { 3. Focus x Leadership Style } \\
\text { Focus_Directive } \\
\text { Focus_Supportive } \\
\text { Focus_Participative } \\
\text { Focus_Achievement }\end{array}$ & & & & & $\begin{array}{l}2.175 \\
-.534 \\
-1.461 \\
-1.764\end{array}$ & $\begin{array}{l}.018^{*} \\
.570 \\
.093 \\
.097\end{array}$ \\
\hline $\begin{array}{l}\text { F-value } \\
\text { R square } \\
\text { Adjusted R square } \\
\text { R square change } \\
\text { F change }\end{array}$ & $\begin{array}{r}27.68 \\
.35 \\
.33 \\
.35 \\
27.68\end{array}$ & & $\begin{array}{r}27.1 \\
.4 \\
.4 \\
.1 \\
17 .\end{array}$ & & $\begin{array}{r}13.82 \\
.5 \\
.53 \\
.05 \\
3.5\end{array}$ & \\
\hline
\end{tabular}

